\title{
Agility Index Evaluation Using Fuzzy Logic in a Supply Chain Management Company
}

\author{
Maryam lotfi ${ }^{1} \&$ Mahmoud Houshmand ${ }^{2}$ \\ ${ }^{1}$ Cass Business School, City University London, London, UK \\ ${ }^{2}$ Industrial Engineering Department, Sharif University of Technology, Tehran, Iran \\ Correspondence: Maryam Lotfi, Cass Business School, City University London, 106 Bunhill Row, London, \\ EC1Y 8TZ, UK. E-mail: Maryam.lotfi.1@cass.city.ac.uk
}

Received: October 19, 2014

Accepted: December 19, 2014 Online Published: April 27, 2015

doi:10.5539/emr.v4n1p64

URL: http://dx.doi.org/10.5539/emr.v4n1p64

\begin{abstract}
Agility is one of the coming challenges to the supply chain management companies. This paper presents a model to evaluate agility for supply chain management companies and answers the question that how agile a supply chain management company is. It shows a complete set of items in evaluating agility in SCM companies. The model surveys agility in responsiveness with indexes such as strategic planning, sensitivity to change and virtual enterprise; flexibility with indexes such as market flexibility, logistics flexibility,operations system flexibility and supply flexibility;competency with indexes such as integrative mechanism, shared culture, joint decision making, trust and communication; and finally quickness with indexes such as speed of new product introduction,delivery time and speed in operation.The results of S.G.S Co. show that it in the middle range of agility. It also identifies weak factors within the organization which by improving them, the company can improve its agility index. Evaluation is done in fuzzy logic.
\end{abstract}

Keywords: agility index, fuzzy logic, supply chain management

\section{Introduction}

The concept of agility was first introduced in a report from the Iacocca Institute at Lehigh University in 1991. The report explained that how US corporations should move forward to become a manufacturing leader again (Nagel \& Dove, 1991).

While agility has been defined in different contexts such as manufacturing, here agility in the context of supply chain is the main concern. A supply chain is a system whose constituent parts include material suppliers, production facilities, distribution services and customers linked together via a feed-forward flow of materials and feedback flow of information Stevenes (1989). This should be expanded to include the flow of resources and cash through the supply chain Naim (1997). Hacland (1997) suggests that the term Supply Chain Management (SCM) can be used to describe a number of concepts - the processes inside a manufacturing organization, purchasing and supply management occurring within dyadic relationships; the total chain and finally a total firm network. It is suggested that the emphasis of supply chain management has changed in the past two deceased. Stuart (1997) and Dossenbach (1999) argue that approaches to supply chain management are much more systematic, focusing on relationships involved.

Christopher and Peck (2004) define supply chain agility as the ability to respond quickly to unpredictable changes in demand or supply. From their point of view, the key to an agile response is the presence of agile partners in upstream and downstream of the focal firm. Christopher and Peck (2004) define the two key characteristics of agile supply chain as visibility (the ability to see from one end of the pipeline to the other) and velocity. Papers related to agility can be mainly divided into two streams. The first category focuses on agility practices and the second group concentrates on how agility affects performance outcomes. These papers have different definition for agility.

Table 1 summarizes the key literature on agility related to both groups and the definitions that are used in these papers for agility. 
Table 1. Key literature on agility and the definitions used

\begin{tabular}{|c|c|c|c|c|}
\hline Paper focus & $\begin{array}{l}\text { Key Literature } \\
\text { on Agility }\end{array}$ & Definition & $\begin{array}{l}\text { Performance } \\
\text { Dimension }\end{array}$ & $\begin{array}{l}\text { Associated } \\
\text { Practices }\end{array}$ \\
\hline \multirow[t]{3}{*}{$\begin{array}{l}\text { Agile } \\
\text { practices }\end{array}$} & $\begin{array}{l}\text { Gunasekaran } \\
\text { and } \quad \text { Yusuf } \\
(2002)\end{array}$ & $\begin{array}{l}\text { "Capability to survive and } \\
\text { prosper in a competitive } \\
\text { environment of continuous } \\
\text { and unpredictable change by } \\
\text { reacting quickly and } \\
\text { effectively to changing } \\
\text { markets, driven by } \\
\text { customer-designed products } \\
\text { and services". }\end{array}$ & & $\begin{array}{l}\text { Flexible people \& } \\
\text { technology, } \\
\text { strategic planning \& } \\
\text { objectives, market } \\
\text { focus }\end{array}$ \\
\hline & $\begin{array}{l}\text { Swafford et al. } \\
(2006)\end{array}$ & $\begin{array}{l}\text { "Capability of an organization } \\
\text { to adapt or react to } \\
\text { marketplace changes or to } \\
\text { seize/exploit market } \\
\text { opportunities with speed and } \\
\text { quickness". }\end{array}$ & & $\begin{array}{l}\text { Procurement, } \\
\text { sourcing flexibility, } \\
\text { manufacturing } \\
\text { flexibility, } \\
\text { distribution, } \\
\text { logistics flexibility }\end{array}$ \\
\hline & $\begin{array}{l}\text { Braunscheidel } \\
\text { and } \quad \text { Suresh } \\
(2009)\end{array}$ & $\begin{array}{l}\text { "Supply chain's capability to } \\
\text { respond in a speedy manner } \\
\text { to a changing marketplace } \\
\text { environment". }\end{array}$ & & $\begin{array}{l}\text { Joint planning, } \\
\text { customer } \\
\text { responsiveness, } \\
\text { visibility, demand, } \\
\text { response }\end{array}$ \\
\hline \multirow[t]{4}{*}{$\begin{array}{l}\text { Agility and } \\
\text { performance }\end{array}$} & $\begin{array}{l}\text { Sharifi and } \\
\text { Zhang (2001) }\end{array}$ & $\begin{array}{l}\text { "Ability to sense, respond to, } \\
\text { and exploit anticipated or } \\
\text { unexpected changes in the } \\
\text { business environment". }\end{array}$ & $\begin{array}{l}\text { Delivery } \\
\text { responsiveness, } \\
\text { delivery speed, } \\
\text { product model } \\
\text { flexibility } \\
\text { (customization), } \\
\text { product } \\
\text { introduction } \\
\text { flexibility, volume } \\
\text { flexibility }\end{array}$ & $\begin{array}{l}\text { Advanced soft \& } \\
\text { hard technologies, } \\
\text { internal networks, } \\
\text { worker } \\
\text { empowerment, } \\
\text { concurrent teams }\end{array}$ \\
\hline & $\begin{array}{l}\text { Prince and Kay } \\
(2003)\end{array}$ & $\begin{array}{l}\text { "Capabilities of an enterprise } \\
\text { to reconfigure itself in } \\
\text { response to sudden changes in } \\
\text { ways that are cost effective, } \\
\text { timely, robust and of broad } \\
\text { scope". }\end{array}$ & $\begin{array}{l}\text { Delivery speed, } \\
\text { product } \\
\text { introduction speed; } \\
\text { stable unit cost, } \\
\text { changeover } \\
\text { flexibility }\end{array}$ & $\begin{array}{l}\text { Information \& } \\
\text { communications } \\
\text { technologies; } \\
\text { computer controlled } \\
\text { manufacturing; } \\
\text { modular facilities } \\
\end{array}$ \\
\hline & $\begin{array}{l}\text { Brown And } \\
\text { Bessant (2003) }\end{array}$ & $\begin{array}{l}\text { "Ability to respond quickly } \\
\text { and effectively to changes in } \\
\text { market demand". }\end{array}$ & $\begin{array}{l}\text { Proactive } r \text { \& } \\
\text { reactive flexibility, } \\
\text { delivery } \quad \text { speed, } \\
\text { design quality } \\
\text { (customization), } \\
\text { cost efficiency }\end{array}$ & $\begin{array}{l}\text { JIT, TQM, customer } \\
\text { linkages, } \\
\text { supplier alliances \& } \\
\text { information } \\
\text { sharing, wide range } \\
\text { of skill training, } \\
\text { advanced } \\
\text { information \& } \\
\text { manufacturing }\end{array}$ \\
\hline & $\begin{array}{l}\text { VasquesBustelo } \\
\text { et al. (2007) }\end{array}$ & $\begin{array}{l}\text { "Capability to change market } \\
\text { requirement, maximize } \\
\text { customer service level, } \\
\text { minimize the cost of goods". }\end{array}$ & $\begin{array}{l}\text { Cost, quality, } \\
\text { delivery, } \\
\text { environment, } \\
\text { flexibility, Service }\end{array}$ & $\begin{array}{l}\text { Agile } \mathrm{HR}, \\
\text { agile technologies, } \\
\text { value chain } \\
\text { integration, } \\
\text { knowledge } \\
\text { management, } \\
\text { concurrent } \\
\text { engineering }\end{array}$ \\
\hline
\end{tabular}


As seen above, different researchers define agility in different ways. This research takes advantage of the one from Swafford et al. (2006). They define agility as "the supply chain's capability to adapt or respond in a speedy manner to a changing marketplace environment". While agility has been researched in literature a lot (Gunasekaran \& Yusuf, 2002; Swafford et al., 2006; Braunscheidel \& Suresh, 2009; Sharifi \& Zhang, 2001; Prince \& Kay, 2003; Brown \& Bessant, 2003; Bustelo et al., 2007) literature still has a deep gap regarding what exactly is agility and how is it define in the context of supply chain and second how agility can be measured in supply chain management companies. The research question is highly important since it is argued that in today's markets competition is no longer based on company versus company model, but instead is supply chain versus supply chain (O’Marah, 2001).

\subsection{Developing Agile Indexes in 3 Grades for Supply Chain Management}

Different researchers present different frameworks for agility. According to Hoek (2000) agility in the supply chain is linked to customer sensitivity, virtual integration, process integration and network integration. Additionally, agile supply chains according to Van der Vorst et al. (2001) are: market sensitive (the supply chain is capable of reading the real demand and responding to it), virtual (using information technology between buyers and suppliers to share the data), process integrated (collaborative working between buyers and suppliers such as joint product development, common systems and shared information) and network based (relationships with partners must be managed in a network, committed to more agile relationships with final customers).Sharifi and Zhang (1999) introduce four agile capabilities in their conceptual model for agility which are responsiveness, competency, flexibility and quickness. We find these capabilities the most comprehensive ones for agile supply chains so we develop our model based on these four capabilities. We define the second and third grade indexes for each of them through other papers which will be mentioned later. The definition and the sub-indexes of these capabilities are as following:

1) Responsiveness is the ability to identify changes and respond to them. This has been itemized as follows:

Strategic planning: subindexes are taken from Gunasekaran et al. (2008) Sensitivity to change: subindexes are taken from Gunasekaran et al. (2008); Lin et al. (2005); Ismail \& Sharifi (2006) Virtual enterprise: subindexes are taken from Gunasekaran et al. (2008); Faisal et al. (2007); and Lin et al. (2006).

2) Competency which is the extensive set of abilities that provides productivity efficiency and effectiveness of activities towards the aims of a company (Sharifi \& Zhang, 1999) and is itemized to: Integrative mechanism, Shared culture, Joint decision making, Trust and Communication. Subindexes are taken from Spekman (2002).

3) Flexibility is the ability to process different products and achieves different objectives with the same facilities (Sharifi \& Zhang, 1999) and is itemized to: Market flexibility, Logrstics flexibility, Operation system flexibility, Supply flexibility. Subindexes are taken from Duclos et al. (2003).

4) Quickness is the ability to do tasks and operations in the shortest time (Sharifi \& Zhang, 1999) and is itemized to: Speed of new product introduction, Delivery time, Speed in operation. Subindexes are taken from Christopher (2000); Sharp et al. (1999); Giachetti et al. (2003); and Lin et al. (2005).

Our agile model developed for SCM companies is presented in Table 2.

Table 2. The agile model developed for SCM companies

\begin{tabular}{|c|c|c|}
\hline $\begin{array}{ll}\left(\mathrm{AC}_{\mathrm{i}}\right) & 1 \text {-Grade } \\
\text { index } & \end{array}$ & $\begin{array}{l}\left(\mathrm{AC}_{\mathrm{ij}}\right) \quad \text { 2-Grade } \\
\text { index }\end{array}$ & $\left(\mathrm{AC}_{\mathrm{ijk}}\right)$ 3-Grade index \\
\hline $\begin{array}{l}1 . \\
\text { Responsiveness }\end{array}$ & $\begin{array}{l}1-1 \quad \text { Strategic } \\
\text { Planning }\end{array}$ & $\begin{array}{l}\mathrm{AC}_{1-1-1} \text { Maintaining and developing relationships with customers } \\
\mathrm{AC}_{1-1-2} \text { Using factors based on customer satisfaction } \\
\mathrm{AC}_{\text {1-1-3 }} \text { Trying for better quality } \\
\mathrm{AC}_{\text {1-1-4 }} \text { Trying for decreasing costs and as a result in cast of product } \\
\mathrm{AC}_{1-1-5} \text { Using multidisciplinary teams } \\
\mathrm{AC}_{1-1-6} \text { Using IT and k.m. systems } \\
\mathrm{AC}_{1-1-7} \text { Top management support } \\
\mathrm{AC}_{\text {1-1-8 }} \text { Having collaborative relationships with suppliers } \\
\mathrm{AC}_{1-1-9} \text { Using concurrent engineering }\end{array}$ \\
\hline
\end{tabular}




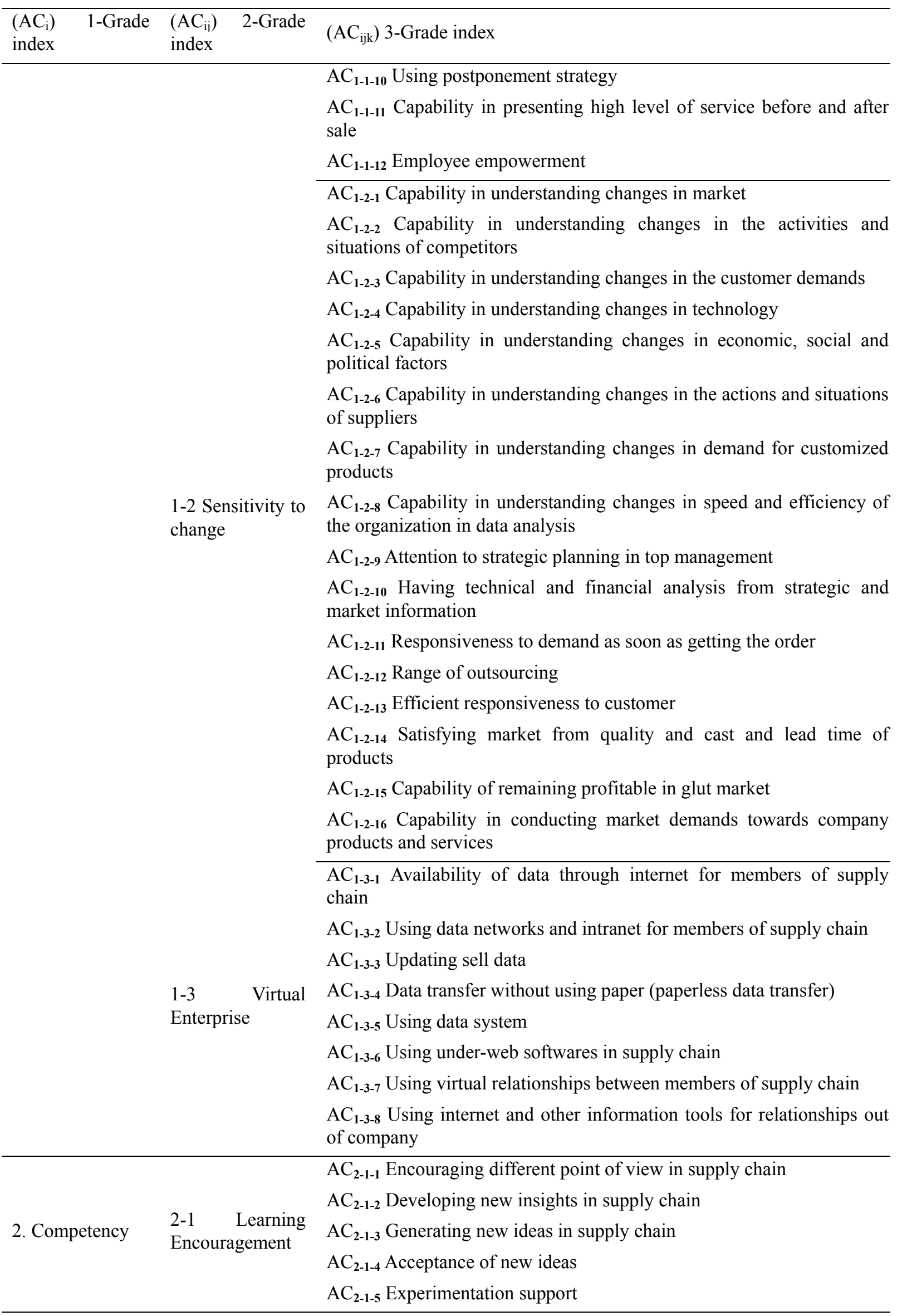




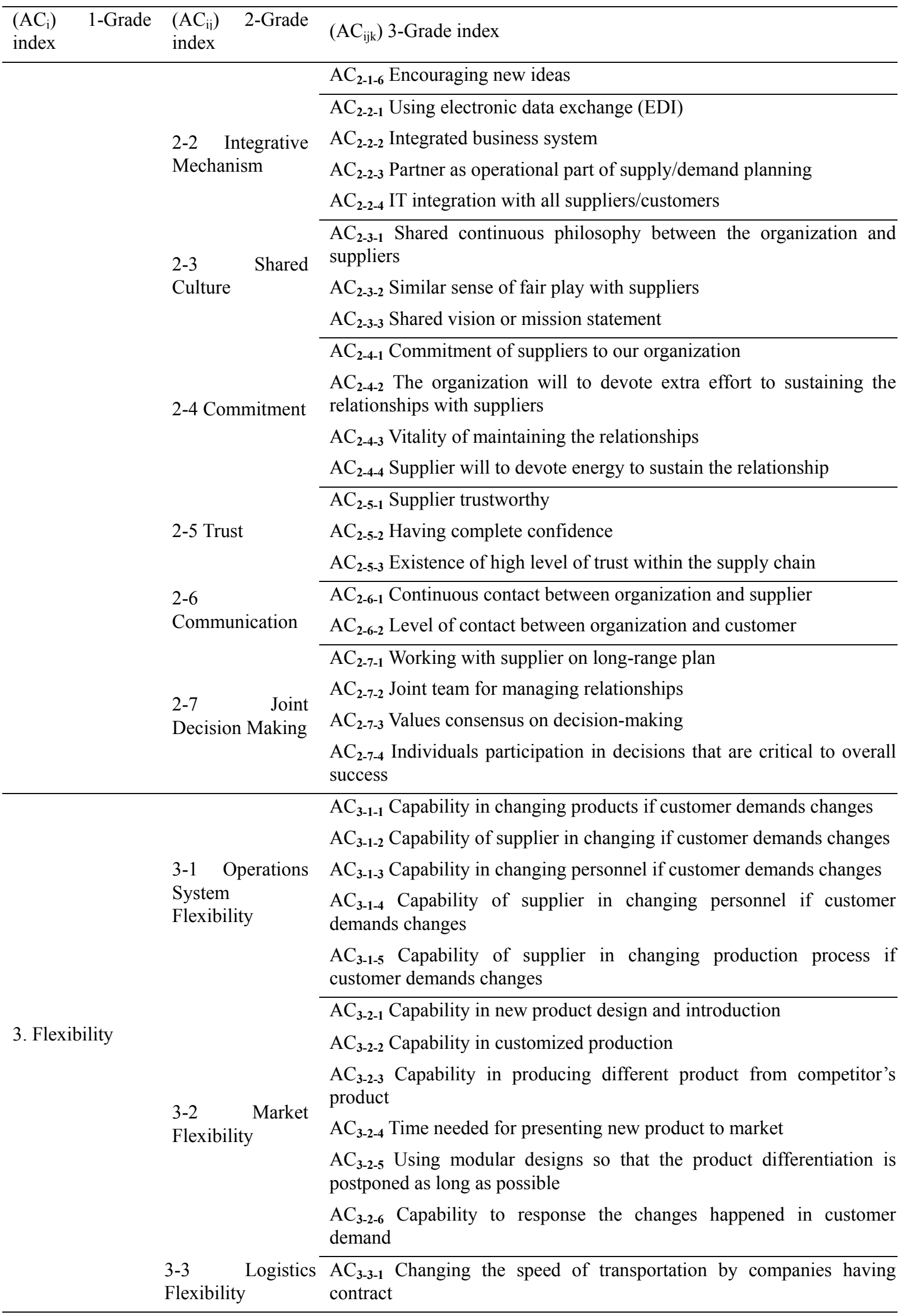




\begin{tabular}{|c|c|c|}
\hline $\begin{array}{l}\left(\mathrm{AC}_{\mathrm{i}}\right) \\
\text { index }\end{array}$ & $\begin{array}{l}\left(\mathrm{AC}_{\mathrm{ij}}\right) \quad 2 \text {-Grade } \\
\text { index }\end{array}$ & $\left(\mathrm{AC}_{\mathrm{ijk}}\right)$ 3-Grade index \\
\hline & & $\begin{array}{l}\mathrm{AC}_{3-3-2} \text { Capability of transportation companies in transporting different } \\
\text { materials }\end{array}$ \\
\hline & & $\begin{array}{l}\mathrm{AC}_{3-3-3} \text { Capability in packaging the production according to customer } \\
\text { demand }\end{array}$ \\
\hline & & $\begin{array}{l}\mathrm{AC}_{3-3-4} \text { Capability of changing documentation method related to good } \\
\text { transportation }\end{array}$ \\
\hline & & $\mathrm{AC}_{3-3-5}$ Capability in tracking transported productions \\
\hline & & $\mathrm{AC}_{3-4-1}$ Number of qualified suppliers for each product \\
\hline & & $\mathrm{AC}_{3-4-2}$ Differences in cost due to buying from different suppliers \\
\hline & & $\mathrm{AC}_{3-4-3}$ Capability of suppliers in supplying different products \\
\hline & & $\begin{array}{l}\mathrm{AC}_{3-4-4} \text { Capability of suppliers in producing in low volumes because of } \\
\text { low storage costs }\end{array}$ \\
\hline & & $\begin{array}{l}\mathrm{AC}_{3-4-5} \text { Existence of different ways and methods for product } \\
\text { transportation from suppliers }\end{array}$ \\
\hline & & $\begin{array}{l}\mathrm{AC}_{3-4-6} \text { Using of min inventory and multi ordering in small batches } \\
\text { policies }\end{array}$ \\
\hline & Flexibility & $\begin{array}{l}\mathrm{AC}_{3-4-7} \text { possibility and transporting different productions within one } \\
\text { batch (economic and technically) }\end{array}$ \\
\hline & & $\begin{array}{l}\mathrm{AC}_{3-4-8} \text { Capability of suppliers in transporting orders quickly with } \\
\text { fastest transportation systems without extra cost }\end{array}$ \\
\hline & & $\mathrm{AC}_{3-4-9}$ Capability to adop processes to specific product \\
\hline & & $\mathrm{AC}_{3-4-10}$ Capability to down size \\
\hline & & $\begin{array}{l}\mathrm{AC}_{3-4-11} \text { Ability to attract a portfolio of partners that changes as } \\
\text { customer needs change }\end{array}$ \\
\hline & & $\begin{array}{l}\mathrm{AC}_{3-4-12} \text { Selection the most appropriate relationships to match the } \\
\text { specific set of circumstances }\end{array}$ \\
\hline \multirow{15}{*}{ 4. Speed } & 4-1 Speed of & $\mathrm{AC}_{4-1-1}$ Speed of understanding new situations in market \\
\hline & New Product & $\mathrm{AC}_{4-1-2}$ Speed of doing research \\
\hline & Introduction & $\mathrm{AC}_{4-1-3}$ Speed of introducing new product to market \\
\hline & & $\mathrm{AC}_{4-2-1}$ Speed in responding changes in customer orders \\
\hline & $\begin{array}{l}\text { 4-2 Delivery on } \\
\text { time }\end{array}$ & $\mathrm{AC}_{4-2-2}$ Speed in making decision \\
\hline & & $\mathrm{AC}_{4-2-3}$ Speed in receiving data related to demands \\
\hline & & $\mathrm{AC}_{4-3-1}$ Speed of capital refund \\
\hline & & $\mathrm{AC}_{4-3-2}$ Speed in receiving necessary data \\
\hline & & $\mathrm{AC}_{4-3-3}$ Speed in a collaboration with a new supplier \\
\hline & & $\mathrm{AC}_{4-3-4}$ Range of availability of data in supply chain \\
\hline & 4-3 Speed & $\mathrm{AC}_{4-3-5}$ Using of virtual relationships in supply chain \\
\hline & Operations & $\begin{array}{l}\mathrm{AC}_{4-3-6} \text { Existence of facilities for quick decision making in supply chain } \\
\text { (for example: intranet) }\end{array}$ \\
\hline & & $\mathrm{AC}_{4-3-7}$ Conducting concurrent activities in supply chain \\
\hline & & $\mathrm{AC}_{4-3-8}$ Speed of stock operation after production delivery \\
\hline & & $\begin{array}{l}\mathrm{AC}_{4-3-9} \text { Speed of preparing documentation related to productions } \\
\text { transportation from stock }\end{array}$ \\
\hline
\end{tabular}


Theoretically this paper present a complete agile model for SCM companies to fill the gap seen in literature previously. It also presents a practical measurement method to evaluate agile index for SCM companies. Practically, managers can take advantage of the comprehensive model to measure their agility index and identify weak factors within their supply chain agility and try to improve them, therefore improve their agility index.

\section{Method}

\subsection{Identifying Agility Index}

Different methods for evaluating agility were mentioned in the literature. Van Hoek proposed integration agility index method as follows:

$$
(\text { Agility index })_{i}=\sum_{j=1}^{N} A_{i j}
$$

Where Aij is the agility level of capability J of company i. Other authors like Ren developed their method on the basis of analytic hierarchical process (AHP). Also Yang and Li define agility as following:

$$
\text { Agility index }=\sum_{i=1}^{N} R_{i} \times W_{i}
$$

Where; $\sum_{i=1}^{\mathrm{N}} \mathrm{W}_{\mathrm{i}}=1$

Where $\mathrm{Ri}$ is agility index and the weight of it is Wi. (Lin et al., 2005)

The above methods are easy to implement but are not suitable for evaluating agility because of the imprecise and vague definition of agility indicators. Also when a situation is characterized by either lack of evidence or the inability of the experts to make a significant assessment of an event, linguistic expressions are used.

The scoring of the above techniques can always be criticized because there are 2 limitations for scoring the agility capabilities. First, such techniques do not take in to account the ambiguity associated with the ones judgment to a number and secondly the subjective judgment and the selection of evaluators have an important influence on those methods.

Here, we used Lin method who used fuzzy logic and linguistic expressions for evaluation because fuzzy logic is suitable for the phenomena which are imprecise and vague. By this method evaluators can use linguistic terms to assess the indicators in a natural language expression and each linguistic term can be associated with a membership function (Lin et al., 2005). The novelty of the research is that the agile capabilities defined in Lin's model were for a product manufacturing company. This model is defined for SCM companies and is developed by comprehensive set of indexes.

We pursued the proposed model by Lin in order to measure how agile the sample company is (This company is introduced in the next section) and also identifying the principal obstacles to improve the agility level. In this approach, the performance ratings and importance weights of different agility capabilities assessed by experts are expressed in logistic terms.

Then appropriate fuzzy numbers are used to present the linguistic values and a simple fuzzy arithmetical operation is employed to synthesize these fuzzy numbers into one fuzzy number, which is called the fuzzy-agility-index (FAI).

Also the FAI is matched with appropriate linguistics; thereby, enabling the agility level to be expressed in linguistic terms. After that the fuzzy performance-importance index (FPII) of each agility capabilities is devised to help managers identify the main adverse factors and calls for managers to institute an appropriate action plan to improve the agility level.

\subsection{Fuzzy Agility Evaluation Approach}

We evaluate agile capabilities and synthesize the ratings and weights to obtain an FAI of an agile SCM and to match FAI with an appropriate agility level and to make an improvement analysis. The steps are as follows:

1) Selecting criteria for evaluation; 
2) Determining the appropriate linguistic scale to assess the performance ratings and importance of agility capabilities using linguistic terms;

3) Measuring the performance and importance weights of the agility capabilities;

4) Approximating the linguistic terms by fuzzy numbers;

5) Aggregating fuzzy ratings with fuzzy weights to obtain and FAI of an enterprise;

6) Matching the FAI with an appropriate level;

7) Analyzing and identify the principal obstacles to improvement.

\section{Results: Agility Evaluation in S.G.S. Co. (The Supply Chain Management Company)}

The above steps for our sample company have been taken as following:

Step 1) The criteria is SazehGostarSaipa Company. S.G.S. Co. has been established in July 1985 and started its formal activity in 1990 as the first company in engineering and supplying automotive parts as well as the first supply chain management and organization of Saipa Group in Iran. The company started its operation by supplying the automotive parts for Nissan.

Widening the range of its activities constantly, SazehGostar has played an outstanding role in the development and progress of the automotive-part producing industry in Iran and currently it covers more than 500 automative-part producers in its supply network.

Step 2) On the basis of the Lin's model and considering the human way of perceiving differences, the linguistic variables $\{$ Excellent $[E]$, Very Good $[\mathrm{VG}]$, Good $[\mathrm{G}]$, Fair $[\mathrm{F}]$, Poor $[\mathrm{P}]$, Very Poor [VP], Worst $[\mathrm{W}]\}$ are selected to assess the performance rating of the agility capabilities and \{Very High [VH],High [H], Fairly High [FH], Medium [M], Fairly Low [FL], Low [L], Very Low [VL]\} are selected to assess the importance weights of the agility capabilities (Lin et al., 2005).

Step 3) 15 persons mostly selected of managers and supervisors, answered the questionnaire about first, second and third indexes of agility. Since analysis through fuzzy logic is complicated 15 persons were selected through those who are at the strategic level of the company in order to understand the importance of all the aspects of strategy, market and competitors. They were selected from different departments such as supply,logistics, human resource, systems and information technology, engineering and development, quality, orders control and marketing, etc.They answered the questionnaires according to the company strategy,characteristics, business changes,marketing information and their knowledge and experience. Some of the results were taken by the interviews especially for those who didn't send back the questionnaires in the time and after emails for recalling the date. They used linguistic terms above to directly measure the performance rating and importance weight of the agility capabilities. Then average operation was used to aggregate the assessments.

$$
\begin{aligned}
& \mathrm{R}_{\mathrm{j}}=\left(\mathrm{R}_{\mathrm{j} 1}(+) \mathrm{R}_{\mathrm{j} 2}(+) \ldots(+) \mathrm{R}_{\mathrm{jm}}\right) / \mathrm{m} \\
& \mathrm{W}_{\mathrm{j}}=\left(\mathrm{W}_{\mathrm{j} 1}(+) \mathrm{W}_{\mathrm{j} 2}(+) \ldots(+) \mathrm{W}_{\mathrm{jm}}\right) / \mathrm{m}
\end{aligned}
$$

Here $m=15$.

The results of aggregated performance ratings and integrated performance weights of agile capabilities measured by linguistic variables are shown in Table 3 .

\begin{tabular}{|c|c|c|c|c|c|c|}
\hline $\mathrm{ACi}$ & ACij & ACijk & Wi & $\mathrm{Wij}_{\mathrm{ij}}$ & Wijk & Rijk \\
\hline \multirow[t]{8}{*}{$\mathrm{ACl}$} & ACl-1 & $1-1 \mathrm{AC} 1$ & $\mathrm{H}$ & $\mathrm{H}$ & $\mathrm{H}$ & $\mathrm{F}$ \\
\hline & & 2-1 $\mathrm{AC} 1$ & & & $\mathrm{FH}$ & $\mathrm{F}$ \\
\hline & & 3-1 AC1 & & & $\mathrm{H}$ & F \\
\hline & & 4-1 $\mathrm{AC} 1$ & & & $\mathrm{H}$ & F \\
\hline & & 5-1 $\mathrm{AC} 1$ & & & $\mathrm{FH}$ & $\mathrm{P}$ \\
\hline & & 6-1 AC1 & & & $\mathrm{H}$ & F \\
\hline & & 7-1 $\mathrm{AC} 1$ & & & $\mathrm{H}$ & F \\
\hline & & 8-1 AC1 & & & $\mathrm{FH}$ & $\mathrm{F}$ \\
\hline
\end{tabular}

Table 3. Aggregated performance rating and aggregated importance weight of agility capabilities 


\begin{tabular}{|c|c|c|c|c|c|c|}
\hline $\mathrm{ACi}$ & ACij & ACijk & Wi & $W_{i j}$ & Wijk & Rijk \\
\hline & & 9-1 AC1 & & & $\mathrm{FH}$ & $\mathrm{P}$ \\
\hline & & $10-1 \mathrm{ACl}$ & & & M & $\mathrm{P}$ \\
\hline & & $11-1 \mathrm{ACl}$ & & & FH & $\mathrm{F}$ \\
\hline & & $12-1 \mathrm{ACl}$ & & & $\mathrm{H}$ & F \\
\hline & $2 \mathrm{AC} 1$ & $1-2 \mathrm{AC} 1$ & & $\mathrm{FH}$ & $\mathrm{FH}$ & $P$ \\
\hline & & 2-2 AC1 & & & $\mathrm{FH}$ & $P$ \\
\hline & & 3-2 AC1 & & & $\mathrm{H}$ & $\mathrm{P}$ \\
\hline & & 4-2 AC1 & & & $\mathrm{H}$ & $P$ \\
\hline & & $5-2 \mathrm{ACl}$ & & & $\mathrm{H}$ & F \\
\hline & & $6-2 \mathrm{ACl}$ & & & FH & $\mathrm{F}$ \\
\hline & & $7-2 \mathrm{ACl}$ & & & FH & $P$ \\
\hline & & 8-2 AC1 & & & FH & $P$ \\
\hline & & $9-2 \mathrm{ACl}$ & & & $\mathrm{H}$ & $\mathrm{F}$ \\
\hline & & $10-2 \mathrm{ACl}$ & & & $\mathrm{H}$ & $P$ \\
\hline & & $11-2 \mathrm{ACl}$ & & & $\mathrm{H}$ & $\mathrm{F}$ \\
\hline & & $12-2 \mathrm{ACl}$ & & & FH & F \\
\hline & & $13-2 \mathrm{ACl}$ & & & $\mathrm{H}$ & G \\
\hline & & $14-2 \mathrm{AC} 1$ & & & $\mathrm{H}$ & F \\
\hline & & $15-2 \mathrm{ACl}$ & & & $\mathrm{FH}$ & $P$ \\
\hline & & $16-2 \mathrm{ACl}$ & & & $\mathrm{H}$ & $P$ \\
\hline & $3 \mathrm{ACl}$ & $1-3 \mathrm{AC} 1$ & & $\mathrm{H}$ & $\mathrm{H}$ & $\mathrm{F}$ \\
\hline & & 2-3 AC1 & & & $\mathrm{H}$ & G \\
\hline & & 3-3 AC1 & & & $\mathrm{FH}$ & G \\
\hline & & 4-3 AC1 & & & $\mathrm{FH}$ & F \\
\hline & & 5-3 AC1 & & & VH & VG \\
\hline & & 6-3 AC1 & & & $\mathrm{H}$ & $\mathrm{F}$ \\
\hline & & 7-3 AC1 & & & $\mathrm{H}$ & $\mathrm{F}$ \\
\hline & & 8-3 AC1 & & & $\mathrm{H}$ & F \\
\hline & & 9-3 AC1 & & & $\mathrm{H}$ & G \\
\hline & & $10-3 \mathrm{ACl}$ & & & $\mathrm{H}$ & F \\
\hline & & $11-3 \mathrm{ACl}$ & & & $\mathrm{H}$ & F \\
\hline \multirow[t]{10}{*}{$\mathrm{AC} 2$} & $1 \mathrm{AC} 2$ & 1-1 AC2 & $\mathrm{H}$ & $\mathrm{H}$ & $\mathrm{H}$ & F \\
\hline & & $2-1 \mathrm{AC} 2$ & & & $\mathrm{H}$ & $\mathrm{G}$ \\
\hline & & 3-1 AC2 & & & $\mathrm{H}$ & $\mathrm{F}$ \\
\hline & & 4-1 AC2 & & & $\mathrm{H}$ & G \\
\hline & & 5-1 AC2 & & & $\mathrm{H}$ & F \\
\hline & & 6-1 AC2 & & & $\mathrm{H}$ & F \\
\hline & $2 \mathrm{AC} 2$ & $1-2 \mathrm{AC} 2$ & & & $\mathrm{H}$ & $\mathrm{G}$ \\
\hline & & $2-2 \mathrm{AC} 2$ & & & $\mathrm{H}$ & F \\
\hline & & 3-2 AC2 & & & $\mathrm{H}$ & $\mathrm{F}$ \\
\hline & & 4-2 AC2 & & & $\mathrm{H}$ & F \\
\hline
\end{tabular}




\begin{tabular}{|c|c|c|c|c|c|c|}
\hline $\mathrm{ACi}$ & ACij & ACijk & Wi & Wij & Wijk & Rijk \\
\hline & $3 \mathrm{AC} 2$ & $1-3 \mathrm{AC} 2$ & & $\mathrm{H}$ & $\mathrm{H}$ & F \\
\hline & & $2-3 \mathrm{AC} 2$ & & & $\mathrm{H}$ & $\mathrm{P}$ \\
\hline & & $3-3 \mathrm{AC} 2$ & & & $\mathrm{H}$ & F \\
\hline & $4 \mathrm{AC} 2$ & 1-4 AC2 & & $\mathrm{H}$ & $\mathrm{H}$ & F \\
\hline & & $2-4 \mathrm{AC} 2$ & & & $\mathrm{H}$ & G \\
\hline & & $3-4 \mathrm{AC} 2$ & & & $\mathrm{H}$ & G \\
\hline & & 4-4 AC2 & & & $\mathrm{H}$ & G \\
\hline & $5 \mathrm{AC} 2$ & 1-5 AC2 & & $\mathrm{H}$ & $\mathrm{H}$ & G \\
\hline & & $2-5 \mathrm{AC} 2$ & & & $\mathrm{H}$ & F \\
\hline & & $3-5 \mathrm{AC} 2$ & & & H & F \\
\hline & $6 \mathrm{AC} 2$ & $1-6 \mathrm{AC} 2$ & & $\mathrm{H}$ & $\mathrm{H}$ & G \\
\hline & & $2-6 \mathrm{AC} 2$ & & & $\mathrm{H}$ & G \\
\hline & $7 \mathrm{AC} 2$ & 1-7 AC2 & & $\mathrm{H}$ & VH & $\mathrm{F}$ \\
\hline & & 2-7 AC2 & & & $\mathrm{H}$ & $\mathrm{F}$ \\
\hline & & 3-7 AC2 & & & $\mathrm{H}$ & F \\
\hline & & 4-7 $\mathrm{AC} 2$ & & & $\mathrm{H}$ & $\mathrm{P}$ \\
\hline \multirow[t]{25}{*}{$\mathrm{AC} 3$} & $1 \mathrm{AC} 3$ & 1-1 AC3 & $\mathrm{H}$ & $\mathrm{H}$ & $\mathrm{H}$ & $\mathrm{F}$ \\
\hline & & 2-1 AC3 & & & $\mathrm{H}$ & G \\
\hline & & 3-1 AC3 & & & $\mathrm{H}$ & F \\
\hline & & 4-1 AC3 & & & $\mathrm{H}$ & F \\
\hline & & $5-1 \mathrm{AC} 3$ & & & $\mathrm{H}$ & F \\
\hline & $2 \mathrm{AC} 3$ & $1-2 \mathrm{AC} 3$ & & $\mathrm{H}$ & $\mathrm{H}$ & F \\
\hline & & $2-2 \mathrm{AC} 3$ & & & $\mathrm{H}$ & $\mathrm{P}$ \\
\hline & & $3-2 \mathrm{AC} 3$ & & & $\mathrm{H}$ & $\mathrm{P}$ \\
\hline & & $4-2 \mathrm{AC} 3$ & & & $\mathrm{H}$ & $\mathrm{P}$ \\
\hline & & $5-2 \mathrm{AC} 3$ & & & $\mathrm{H}$ & $\mathrm{P}$ \\
\hline & & 6-2 $\mathrm{AC} 3$ & & & $\mathrm{H}$ & G \\
\hline & $3 \mathrm{AC} 3$ & 1-3 AC3 & & $\mathrm{H}$ & $\mathrm{H}$ & $\mathrm{F}$ \\
\hline & & 2-3 AC3 & & & $\mathrm{H}$ & $\mathrm{F}$ \\
\hline & & 3-3 AC3 & & & $\mathrm{H}$ & G \\
\hline & & 4-3 AC3 & & & FH & P \\
\hline & & 5-3 AC3 & & & $\mathrm{H}$ & $\mathrm{P}$ \\
\hline & AC3-4 & 1-4 AC3 & & $\mathrm{H}$ & $\mathrm{H}$ & $\mathrm{F}$ \\
\hline & & $2-4 \mathrm{AC} 3$ & & & $\mathrm{H}$ & F \\
\hline & & $3-4 \mathrm{AC} 3$ & & & $\mathrm{H}$ & $\mathrm{F}$ \\
\hline & & 4-4 $\mathrm{AC} 3$ & & & $\mathrm{H}$ & $\mathrm{F}$ \\
\hline & & 5-4 AC3 & & & $\mathrm{H}$ & F \\
\hline & & 6-4 AC3 & & & $\mathrm{FH}$ & F \\
\hline & & 7-4 AC3 & & & $\mathrm{FH}$ & $P$ \\
\hline & & $8-4 \mathrm{AC} 3$ & & & $\mathrm{H}$ & $\mathrm{F}$ \\
\hline & & $9-4 \mathrm{AC} 3$ & & & $\mathrm{H}$ & $\mathrm{F}$ \\
\hline
\end{tabular}




\begin{tabular}{|c|c|c|c|c|c|c|}
\hline $\mathrm{ACi}$ & $\mathrm{ACij}$ & ACijk & Wi & Wij & Wijk & Rijk \\
\hline & & 10-4- AC3 & & & $\mathrm{FH}$ & $\mathrm{P}$ \\
\hline & & 11-4 AC3 & & & $\mathrm{H}$ & F \\
\hline & & $12-4 \mathrm{AC} 3$ & & & $\mathrm{H}$ & $\mathrm{F}$ \\
\hline \multirow[t]{15}{*}{$\mathrm{AC} 4$} & $1 \mathrm{AC} 4$ & $1-1 \mathrm{AC} 4$ & $\mathrm{H}$ & & $\mathrm{FH}$ & $\mathrm{P}$ \\
\hline & & $2-1 \mathrm{AC} 4$ & & & $\mathrm{H}$ & $\mathrm{P}$ \\
\hline & & 3-1 AC4 & & & $\mathrm{H}$ & $\mathrm{P}$ \\
\hline & $2 \mathrm{AC} 4$ & $1-2 \mathrm{AC} 4$ & $\mathrm{H}$ & & $\mathrm{H}$ & $\mathrm{P}$ \\
\hline & & $2-2 \mathrm{AC} 4$ & & & $\mathrm{H}$ & F \\
\hline & & 3-2 AC4 & & & $\mathrm{H}$ & G \\
\hline & $3 \mathrm{AC} 4$ & $1-3 \mathrm{AC} 4$ & $\mathrm{H}$ & & $\mathrm{H}$ & F \\
\hline & & 2-3 AC4 & & & $\mathrm{H}$ & F \\
\hline & & 3-3 AC4 & & & $\mathrm{H}$ & F \\
\hline & & $4-3 \mathrm{AC} 4$ & & & $\mathrm{H}$ & F \\
\hline & & 5-3 AC4 & & & $\mathrm{H}$ & F \\
\hline & & 6-3 AC4 & & & $\mathrm{H}$ & G \\
\hline & & 7-3 AC4 & & & $\mathrm{H}$ & F \\
\hline & & 8-3 AC4 & & & $\mathrm{H}$ & G \\
\hline & & $9-3 \mathrm{AC} 4$ & & & $\mathrm{H}$ & $\mathrm{F}$ \\
\hline
\end{tabular}

Step 4) according to Lin et al. (2005) a set of fuzzy numbers for approximating linguistic variable values was developed as listed in Table 4.

Table 4. Fuzzy numbers for approximating linguistic variable values

\begin{tabular}{llll}
\hline Performance-rating & & Importance-weighting \\
\hline Linguistic vriable & Fuzzy number & Linguistic variable & Fuzzy number \\
$(1)$ Worst (W) & $(0,0.5,1.5)$ & $(1)$ Very Low (VL) & $(0,0.05,0.15)$ \\
(2)Very Poor (VP) & $(1,2,3)$ & $(2)$ Low (L) & $(0.1,0.2,0.3)$ \\
(3)Poor (P) & $(2,3.5,5)$ & $(3)$ Fairly Low (FL) & $(0.2,0.35,0.5)$ \\
(4)Fair (F) & $(3,5,7)$ & $(4)$ Medium (M) & $(0.3,0.5,0.7)$ \\
(5)Good (G) & $(5,6.5,8)$ & $(5)$ Fairly high (FH) & $(0.5,0.65,0.8)$ \\
(6)Very Good (VG) & $(7,8,9)$ & $(6)$ High (H) & $(0.7,0.8,0.9)$ \\
(7)Excellent (E) & $(8.5,9.5,10)$ & (7)Very High (VH) & $(0.85,0.95,0.1)$ \\
\hline
\end{tabular}

Then the relation between linguistic terms and fuzzy numbers was applied and the linguistic numbers in Table 3were transferred in to fuzzy numbers.

Step 5) FAI is an information fusion, which consolidate the fuzzy ratings and fuzzy weights, of all the factors that influence the agility. FAI represents overall enterprise agility.

The membership function of FAI is used to determine the agility level. According to the fuzzy index of the agility the ACij can be calculated as:

$$
\mathrm{AC}_{\mathrm{ij}}=\sum_{\mathrm{k}=\mathrm{W}_{\mathrm{ijk}}}^{\mathrm{n}} \otimes \mathrm{AC}_{\mathrm{ijk}} / \sum_{\mathrm{k}=1}^{\mathrm{n}} \mathrm{W}_{\mathbf{i j k}}
$$

Where ACij and Wijk respective lyre present the fuzzy performancé rating and fuzzy importance weight of the agility element capability. Fuzzy index of each grade of agility capabilities are calculated from formula 5 and are presented in Table 5. 
Table 5. Fuzzy index of each grade of agility capabilities

\begin{tabular}{|c|c|c|c|}
\hline $\mathrm{AC}_{\mathrm{i}}$ & $\mathrm{AC}_{\mathrm{ij}}$ & $\mathrm{R}_{\mathrm{ij}}$ & $\mathrm{R}_{\mathrm{ijk}}$ \\
\hline \multirow[t]{3}{*}{$\mathrm{AC}_{1}$} & ${ }_{1-} \mathrm{AC}_{1}$ & $3.2,4.8,7.9)($ & $(2.8,4.9,10.2)$ \\
\hline & 2- $\mathrm{AC}_{1}$ & & $(2.6,3.7,5.9)$ \\
\hline & 3- $\mathrm{AC}_{1}$ & & $(3.9,5.7,7.5)$ \\
\hline \multirow[t]{7}{*}{$\mathrm{AC}_{2}$} & ${ }_{1-} \mathrm{AC}_{2}$ & $3.7,4.8,7.1)($ & $(3.7,5.3,7.3)$ \\
\hline & 2- $\mathrm{AC}_{2}$ & & $(3.5,5.4,7.3)$ \\
\hline & 3- $\mathrm{AC}_{2}$ & & $(2.6,4.5,6.3)$ \\
\hline & 4- $\mathrm{AC}_{2}$ & & $(4.5,4.5,7.8)$ \\
\hline & 5- $\mathrm{AC}_{2}$ & & $(3.6,5.5,7.3)$ \\
\hline & 6- $\mathrm{AC}_{2}$ & & $(5,6.5,8)$ \\
\hline & 7- $\mathrm{AC}_{2}$ & & $(2.8,1.7,6.5)$ \\
\hline \multirow[t]{3}{*}{$\mathrm{AC}_{3}$} & ${ }_{1-} \mathrm{AC}_{3}$ & $(4,4.3,7.4)$ & $(3.4,5.3,10.8)$ \\
\hline & 2- $\mathrm{AC}_{3}$ & & $(2.6,2.5,5.8)$ \\
\hline & 3- $\mathrm{AC}_{3}$ & & $(7.2,4.8,6.4)$ \\
\hline \multirow[t]{3}{*}{$\mathrm{AC}_{4}$} & 1- $\mathrm{AC}_{4}$ & $(2.9,4.6,6.3)$ & $(2,3.5,5)$ \\
\hline & 2- $\mathrm{AC}_{4}$ & & $(3.3,5,6.6)$ \\
\hline & 3- $\mathrm{AC}_{4}$ & & $(2.9,4.6,6.3)$ \\
\hline
\end{tabular}

Finally FAI is calculated as following:FAI $=[(0.7,0.8,0.9) \otimes(3.2,4.8,7.9) \oplus(0.7,0.8,0.9) \otimes(3.7,4.8,7.1) \oplus$ $(0.7,0.8,0.9) \oplus(4,4.3,7.4) \oplus(7,0.8,0.9) \otimes(2.9,4.6,6.3)] /[(0.7,0.8,0.9) \oplus(0.7,0.8,0.9) \oplus(0.7,0.8,0.9) \oplus$ $(7,0.8,0.9)]=(3.4,4.6,7.2)$

Step 6) Once the FAI has been obtained to identify the level of agility, the FAI can be further matched with the linguistic label whose membership function is the same as (or closest to) the membership function of the FAI from the natural-language expression set of agility label (AL).

It is recommended that the Euclidean distance method be utilized because it is the most intuitive form of human perception of proximity.

In this case the natural-language expression set $\mathrm{AL}=$ \{Extremely Agile [EA], Very Agile [VA], Agile [A], Fairly $[\mathrm{F}]$, Slowly $[\mathrm{S}]\}$ is selected for labeling and corresponding membership functions are shown in Fig 1.

Fuzzy set of $\mathrm{S}$ is $(0,1.5,3)$, fuzzy set of $\mathrm{F}$ is $(1.5,3,4.5)$, fuzzy set of $\mathrm{A}$ is $(3.5,5,6.5)$, fuzzy set of VA is $(5.5,7$, 8.5 ) and fuzzy set of EA is $(7,8.5,10)$ (Lin et al., 2005).

Then by using the Euclidean distance method, the Euclidean distance D from the FAI to each member in set AL is calculated.

$$
\mathrm{D}\left(\mathrm{FAI}, \mathrm{AL}_{\mathrm{i}}\right)=\left\{\sum_{\mathbf{x} \in \rho}\left(\mathrm{f}_{\mathrm{FAI}}(\mathrm{x})-\mathrm{f}_{\mathrm{ALi}}(\mathrm{x})\right)^{2}\right\}^{1 / 2}
$$

$$
\mathrm{P}=\{\mathrm{x} 0, \mathrm{x} 1, \ldots, \mathrm{xm}\} \subset[0,10] \text { so } 0=\mathrm{x} 0<\mathrm{x} 1<\ldots<\mathrm{xm}=10 \text { to simplify let } \mathrm{P}=\{0,0.5,1, \ldots, 9.5,10\}
$$

Is the function of fuzzy set $(a, b, c)$

$$
\text { Where } f_{A}(x)=\left\{\begin{array}{cc}
(x-a) /(b-a) & a \leq x \leq b \\
0 & \text { otherwise }
\end{array}\right.
$$

$\mathrm{D}($ FAI, EA $)=2.63739 / \mathrm{D}($ FAI, VA $)=2.71944 / \mathrm{D}(\mathrm{FAI}, \mathrm{A})=2.50144 / \mathrm{D}($ FAI, F $)=2.87548 / \mathrm{D}($ FAI, S $)=2.6373$ 
Thus by matching a linguistic label with the minimum D, the agility index level of S.G.S can be identified as agile as shown in Fig. 1.

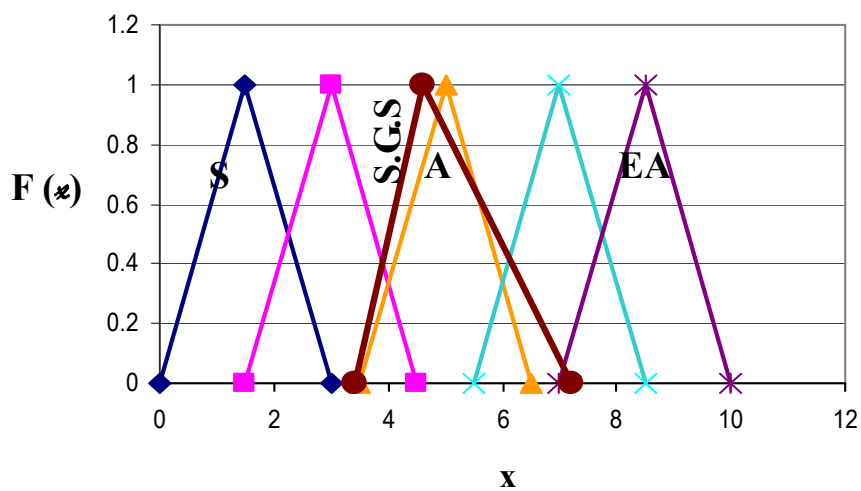

Figure 1. Linguistic levels to match FAI

Step 7) For identifying principal obstacles (low performance rating and high importance) we must have score for each of agility indexes in order to compare them with each other .So FpII (fuzzy performance-importance index) is defined as follows:

Calculated $\mathbf{F}_{\text {pII }}$ are shown in Table 6.

$$
\begin{aligned}
& \mathrm{F}_{\mathrm{pII}}=\mathrm{W}^{\prime}{ }_{\mathrm{ijk}} \otimes \mathrm{AC}_{\mathrm{ijk}} \\
& \mathrm{W}^{\prime}{ }_{\mathrm{ijk}}=(1,1,1) \ominus \mathrm{W}_{\mathrm{ijk}}
\end{aligned}
$$

\begin{tabular}{|c|c|c|c|c|c|}
\hline $\begin{array}{l}\text { Agility } \\
\text { Capability }\end{array}$ & \begin{tabular}{ll}
\multicolumn{2}{l}{ Aggregated } \\
Fuzzy $\quad$ Perf. \\
Rating
\end{tabular} & $\mathrm{W}_{\mathrm{ijk}}$ & $\mathrm{W}_{\mathrm{ijk}}-(1,1,1)$ & $\mathrm{FpII}_{\mathrm{ijk}}$ & $\begin{array}{l}\text { Ranking } \\
\text { Score }\end{array}$ \\
\hline 1-1- $\mathrm{AC}_{1}$ & $(3,5,7)$ & $(0.7,0.8,0.9)$ & $(0.1,0.2,0.3)$ & $(0.3,1,2.1)$ & 1.413 \\
\hline 2-1- $\mathrm{AC}_{1}$ & $(3,5,7)$ & $(0.5,0.65,0.8)$ & $(0.2,0.35,0.5)$ & $(0.6,1.75,3.5)$ & 2.274 \\
\hline 3-1- $\mathrm{AC}_{1}$ & $(3,5,7)$ & $(0.7,0.8,0.9)$ & $(0.1,0.2,0.3)$ & $(0.3,1,2.1)$ & 1.413 \\
\hline 4-1- $\mathrm{AC}_{1}$ & $(3,5,7)$ & $(0.7,0.8,0.9)$ & $(0.1,0.2,0.3)$ & $(0.3,1,2.1)$ & 1.413 \\
\hline 5-1- $\mathrm{AC}_{1}$ & $(2,3.5,5)$ & $(0.5,0.65,0.8)$ & $(0.2,0.35,0.5)$ & $(0.4,1.26,2.5)$ & 1.627 \\
\hline 6-1- $\mathrm{AC}_{1}$ & $(3,5,7)$ & $(0.7,0.8,0.9)$ & $(0.1,0.2,0.3)$ & $(0.3,1,2.1)$ & 1.413 \\
\hline 7-1- $\mathrm{AC}_{1}$ & $(3,5,7)$ & $(0.7,0.8,0.9)$ & $(0.1,0.2,0.3)$ & $(0.3,1,2.1)$ & 1.413 \\
\hline${ }_{8-1-1-} \mathrm{AC}_{1}$ & $(3,5,7)$ & $(0.5,0.65,0.8)$ & $(0.2,0.35,0.5)$ & $(0.6,1.75,3.5)$ & 2.274 \\
\hline 9-1- $\mathrm{AC}_{1}$ & $(2,3.5,5)$ & $(0.5,0.65,0.8)$ & $(0.2,0.35,0.5)$ & $(0.4,1.26,2.5)$ & 1.627 \\
\hline 10-1- $\mathrm{AC}_{1}$ & $(2,3.5,5)$ & $(0.3,0.5,0.7)$ & $(0.3,0.5,0.7)$ & $(0.6,1.75,3.5)$ & 1.985 \\
\hline 11-1- $\mathrm{AC}_{1}$ & $(3,5,7)$ & $(0.5,0.65,0.8)$ & $(0.2,0.35,0.5)$ & $(0.6,1.75,3.5)$ & 2.274 \\
\hline 12-1- $\mathrm{AC}_{1}$ & $(3,5,7)$ & $(0.7,0.8,0.9)$ & $(0.1,0.2,0.3)$ & $(0.3,1,2.1)$ & 1.413 \\
\hline 1-2- $\mathrm{AC}_{1}$ & $(2,3.5,5)$ & $(0.5,0.65,0.8)$ & $(0.2,0.35,0.5)$ & $(0.4,1.26,2.5)$ & 1.627 \\
\hline 2-2- $\mathrm{AC}_{1}$ & $(2,3.5,5)$ & $(0.5,0.65,0.8)$ & $(0.2,0.35,0.5)$ & $(0.4,1.26,2.5)$ & 1.627 \\
\hline 3-2- $\mathrm{AC}_{1}$ & $(2,3.5,5)$ & $(0.7,0.8,0.9)$ & $(0.1,0.2,0.3)$ & $(0.2,0.7,1.5)$ & 1.028 \\
\hline 4-2- $\mathrm{AC}_{1}$ & $(2,3.5,5)$ & $(0.7,0.8,0.9)$ & $(0.1,0.2,0.3)$ & $(0.2,0.7,1.5)$ & 1.028 \\
\hline 5-2- $\mathrm{AC}_{1}$ & $(3,5,7)$ & $(0.7,0.8,0.9)$ & $(0.1,0.2,0.3)$ & $(0.3,1,2.1)$ & 1.413 \\
\hline 6-2- $\mathrm{AC}_{1}$ & $(3,5,7)$ & $(0.5,0.65,0.8)$ & $(0.2,0.35,0.5)$ & $(0.6,1.75,3.5)$ & 2.274 \\
\hline
\end{tabular}

Table 6. Fuzzy performance-importance indexes of agility capabilities 


\begin{tabular}{|c|c|c|c|c|c|}
\hline $\begin{array}{l}\text { Agility } \\
\text { Capability }\end{array}$ & \begin{tabular}{ll}
\multicolumn{2}{l}{ Aggregated } \\
Fuzzy Perf. \\
Rating
\end{tabular} & $\mathrm{W}_{\mathrm{ijk}}$ & $\mathrm{W}_{\mathrm{ijk}}-(1,1,1)$ & $\mathrm{FpII}_{\mathrm{ijk}}$ & $\begin{array}{l}\text { Ranking } \\
\text { Score }\end{array}$ \\
\hline 7-2- $\mathrm{AC}_{1}$ & $(2,3.5,5)$ & $(0.5,0.65,0.8)$ & $(0.2,0.35,0.5)$ & $(0.4,1.26,2.5)$ & 1.627 \\
\hline 8-2- $\mathrm{AC}_{1}$ & $(2,3.5,5)$ & $(0.5,0.65,0.8)$ & $(0.2,0.35,0.5)$ & $(0.4,1.26,2.5)$ & 1.627 \\
\hline 9-2- $\mathrm{AC}_{1}$ & $(3,5,7)$ & $(0.7,0.8,0.9)$ & $(0.1,0.2,0.3)$ & $(0.3,1,2.1)$ & 1.413 \\
\hline 10-2- $\mathrm{AC}_{1}$ & $(2,3.5,5)$ & $(0.7,0.8,0.9)$ & $(0.1,0.2,0.3)$ & $(0.2,0.7,1.5)$ & 1.028 \\
\hline 11-2- $\mathrm{AC}_{1}$ & $(3,5,7)$ & $(0.7,0.8,0.9)$ & $(0.1,0.2,0.3)$ & $(0.3,1,2.1)$ & 1.413 \\
\hline 12-2- $\mathrm{AC}_{1}$ & $(3,5,7)$ & $(0.5,0.65,0.8)$ & $(0.2,0.35,0.5)$ & $(0.6,1.75,3.5)$ & 2.274 \\
\hline 13-2- $\mathrm{AC}_{1}$ & $(2,3.5,5)$ & $(0.7,0.8,0.9)$ & $(0.1,0.2,0.3)$ & $(0.5,1.3,2.4)$ & 1.703 \\
\hline 14-2- $\mathrm{AC}_{1}$ & $(3,5,7)$ & $(0.7,0.8,0.9)$ & $(0.1,0.2,0.3)$ & $(0.3,1,2.1)$ & 1.413 \\
\hline 15-2- $\mathrm{AC}_{1}$ & $(2,3.5,5)$ & $(0.5,0.65,0.8)$ & $(0.2,0.35,0.5)$ & $(0.4,1.26,2.5)$ & 1.627 \\
\hline 16-2- $\mathrm{AC}_{1}$ & $(2,3.5,5)$ & $(0.7,0.8,0.9)$ & $(0.1,0.2,0.3)$ & $(0.2,0.7,1.5)$ & 1.028 \\
\hline 1-3- $\mathrm{AC}_{1}$ & $(3,5,7)$ & $(0.7,0.8,0.9)$ & $(0.1,0.2,0.3)$ & $(0.3,1,2.1)$ & 1.413 \\
\hline 2-3- $\mathrm{AC}_{1}$ & $(5,6.5,8)$ & $(0.7,0.8,0.9)$ & $(0.1,0.2,0.3)$ & $(0.5,1.3,2.4)$ & 1.703 \\
\hline 3-3- $\mathrm{AC}_{1}$ & $(5,6.5,8)$ & $(0.5,0.65,0.8)$ & $(0.2,0.35,0.5)$ & $(1,2.275,4)$ & 2.715 \\
\hline 4-3- $\mathrm{AC}_{1}$ & $(3,5,7)$ & $(0.5,0.65,0.8)$ & $(0.2,0.35,0.5)$ & $(0.6,1.75,3.5)$ & 2.274 \\
\hline 5-3- $\mathrm{AC}_{1}$ & $(7,8,9)$ & $(0.7,0.8,0.9)$ & $(0.1,0.2,0.3)$ & $(0.7,1.6,2.7)$ & 1.95 \\
\hline 6-3- $\mathrm{AC}_{1}$ & $(3,5,7)$ & $(0.7,0.8,0.9)$ & $(0.1,0.2,0.3)$ & $(0.3,1,2.1)$ & 1.413 \\
\hline 7-3- $\mathrm{AC}_{1}$ & $(3,5,7)$ & $(0.7,0.8,0.9)$ & $(0.1,0.2,0.3)$ & $(0.3,1,2.1)$ & 1.413 \\
\hline 8-3- $\mathrm{AC}_{1}$ & $(3,5,7)$ & $(0.7,0.8,0.9)$ & $(0.1,0.2,0.3)$ & $(0.3,1,2.1)$ & 1.413 \\
\hline 9-3- $\mathrm{AC}_{1}$ & $(5,6.5,8)$ & $(0.7,0.8,0.9)$ & $(0.1,0.2,0.3)$ & $(0.5,1.3,2.4)$ & 1.703 \\
\hline 10-3- $\mathrm{AC}_{1}$ & $(3,5,7)$ & $(0.7,0.8,0.9)$ & $(0.1,0.2,0.3)$ & $(0.3,1,2.1)$ & 1.413 \\
\hline${ }_{11-3-}-\mathrm{AC}_{1}$ & $(3,5,7)$ & $(0.7,0.8,0.9)$ & $(0.1,0.2,0.3)$ & $(0.3,1,2.1)$ & 1.413 \\
\hline 1-1- $\mathrm{AC}_{2}$ & $(3,5,7)$ & $(0.7,0.8,0.9)$ & $(0.1,0.2,0.3)$ & $(0.3,1,2.1)$ & 1.413 \\
\hline 2-1- $\mathrm{AC}_{2}$ & $(5,6.5,8)$ & $(0.7,0.8,0.9)$ & $(0.1,0.2,0.3)$ & $(0.5,1.3,2.4)$ & 1.703 \\
\hline 3-1- $\mathrm{AC}_{2}$ & $(3,5,7)$ & $(0.7,0.8,0.9)$ & $(0.1,0.2,0.3)$ & $(0.3,1,2.1)$ & 1.413 \\
\hline 4-1- $\mathrm{AC}_{2}$ & $(5,6.5,8)$ & $(0.7,0.8,0.9)$ & $(0.1,0.2,0.3)$ & $(0.5,1.3,2.4)$ & 1.703 \\
\hline 5-1- $\mathrm{AC}_{2}$ & $(3,5,7)$ & $(0.7,0.8,0.9)$ & $(0.1,0.2,0.3)$ & $(0.3,1,2.1)$ & 1.413 \\
\hline 6-1- $\mathrm{AC}_{2}$ & $(3,5,7)$ & $(0.7,0.8,0.9)$ & $(0.1,0.2,0.3)$ & $(0.3,1,2.1)$ & 1.413 \\
\hline 1-2- $\mathrm{AC}_{2}$ & $(5,6.5,8)$ & $(0.7,0.8,0.9)$ & $(0.1,0.2,0.3)$ & $(0.5,1.3,2.4)$ & 1.703 \\
\hline 2-2- $\mathrm{AC}_{2}$ & $(3,5,7)$ & $(0.7,0.8,0.9)$ & $(0.1,0.2,0.3)$ & $(0.3,1,2.1)$ & 1.413 \\
\hline 3-2- $\mathrm{AC}_{2}$ & $(3,5,7)$ & $(0.7,0.8,0.9)$ & $(0.1,0.2,0.3)$ & $(0.3,1,2.1)$ & 1.413 \\
\hline 4-2- $\mathrm{AC}_{2}$ & $(3,5,7)$ & $(0.7,0.8,0.9)$ & $(0.1,0.2,0.3)$ & $(0.3,1,2.1)$ & 1.413 \\
\hline 1-3- $\mathrm{AC}_{2}$ & $(3,5,7)$ & $(0.7,0.8,0.9)$ & $(0.1,0.2,0.3)$ & $(0.3,1,2.1)$ & 1.413 \\
\hline 2-3- $\mathrm{AC}_{2}$ & $(2,3.5,5)$ & $(0.7,0.8,0.9)$ & $(0.1,0.2,0.3)$ & $(0.1,0.7,1.5)$ & 1.028 \\
\hline 3-3- $\mathrm{AC}_{2}$ & $(3,5,7)$ & $(0.7,0.8,0.9)$ & $(0.1,0.2,0.3)$ & $(0.3,1,2.1)$ & 1.413 \\
\hline 1-4- $\mathrm{AC}_{2}$ & $(3,5,7)$ & $(0.7,0.8,0.9)$ & $(0.1,0.2,0.3)$ & $(0.3,1,2.1)$ & 1.413 \\
\hline 2-4. $\mathrm{AC}_{2}$ & $(5,6.5,8)$ & $(0.7,0.8,0.9)$ & $(0.1,0.2,0.3)$ & $(0.5,1.3,2.4)$ & 1.703 \\
\hline 3-4. $\mathrm{AC}_{2}$ & $(5,6.5,8)$ & $(0.7,0.8,0.9)$ & $(0.1,0.2,0.3)$ & $(0.5,1.3,2.4)$ & 1.703 \\
\hline 4-4- $\mathrm{AC}_{2}$ & $(5,6.5,8)$ & $(0.7,0.8,0.9)$ & $(0.1,0.2,0.3)$ & $(0.5,1.3,2.4)$ & 1.703 \\
\hline 1-5- $\mathrm{AC}_{2}$ & $(5,6.5,8)$ & $(0.7,0.8,0.9)$ & $(0.1,0.2,0.3)$ & $(0.5,1.3,2.4)$ & 1.703 \\
\hline
\end{tabular}




\begin{tabular}{|c|c|c|c|c|c|}
\hline $\begin{array}{l}\text { Agility } \\
\text { Capability }\end{array}$ & $\begin{array}{l}\text { Aggregated } \\
\text { Fuzzy Perf. } \\
\text { Rating }\end{array}$ & $\mathrm{W}_{\mathrm{ijk}}$ & $\mathrm{W}_{\mathrm{ijk}}-(1,1,1)$ & $\mathrm{FpII}_{\mathrm{ijk}}$ & $\begin{array}{l}\text { Ranking } \\
\text { Score }\end{array}$ \\
\hline 2-5- $\mathrm{AC}_{2}$ & $(3,5,7)$ & $(0.7,0.8,0.9)$ & $(0.1,0.2,0.3)$ & $(0.3,1,2.1)$ & 1.413 \\
\hline 3-5- $\mathrm{AC}_{2}$ & $(3,5,7)$ & $(0.7,0.8,0.9)$ & $(0.1,0.2,0.3)$ & $(0.3,1,2.1)$ & 1.413 \\
\hline 1-6- $\mathrm{AC}_{2}$ & $(5,6.5,8)$ & $(0.7,0.8,0.9)$ & $(0.1,0.2,0.3)$ & $(0.5,1.3,2.4)$ & 1.703 \\
\hline 2-6- $\mathrm{AC}_{2}$ & $(5,6.5,8)$ & $(0.7,0.8,0.9)$ & $(0.1,0.2,0.3)$ & $(0.5,1.3,2.4)$ & 1.703 \\
\hline 1-7. $\mathrm{AC}_{2}$ & $(3,5,7)$ & $(0.85,0.95,1)$ & $(0,0.05,0.15)$ & $(0,0.25,1.05)$ & 0.324 \\
\hline 2-7.- $\mathrm{AC}_{2}$ & $(3,5,7)$ & $(0.7,0.8,0.9)$ & $(0.1,0.2,0.3)$ & $(0.3,1,2.1)$ & 1.413 \\
\hline 3-7. $\mathrm{AC}_{2}$ & $(3,5,7)$ & $(0.7,0.8,0.9)$ & $(0.1,0.2,0.3)$ & $(0.3,1,2.1)$ & 1.413 \\
\hline 4-7. $\mathrm{AC}_{2}$ & $(2,3.5,5)$ & $(0.7,0.8,0.9)$ & $(0.1,0.2,0.3)$ & $(0.2,0.7,1.5)$ & 1.028 \\
\hline 1-1- $\mathrm{AC}_{3}$ & $(3,5,7)$ & $(0.7,0.8,0.9)$ & $(0.1,0.2,0.3)$ & $(0.3,1,2.1)$ & 1.413 \\
\hline 2-1- $\mathrm{AC}_{3}$ & $(5,6.5,8)$ & $(0.7,0.8,0.9)$ & $(0.1,0.2,0.3)$ & $(0.5,1.3,2.4)$ & 1.703 \\
\hline 3-1- $\mathrm{AC}_{3}$ & $(3,5,7)$ & $(0.7,0.8,0.9)$ & $(0.1,0.2,0.3)$ & $(0.3,1,2.1)$ & 1.413 \\
\hline 4-1- $\mathrm{AC}_{3}$ & $(3,5,7)$ & $(0.7,0.8,0.9)$ & $(0.1,0.2,0.3)$ & $(0.3,1,2.1)$ & 1.413 \\
\hline 5-1- $\mathrm{AC}_{3}$ & $(3,5,7)$ & $(0.7,0.8,0.9)$ & $(0.1,0.2,0.3)$ & $(0.3,1,2.1)$ & 1.413 \\
\hline 1-2- $\mathrm{AC}_{3}$ & $(3,5,7)$ & $(0.7,0.8,0.9)$ & $(0.1,0.2,0.3)$ & $(0.3,1,2.1)$ & 1.413 \\
\hline 2-2- $\mathrm{AC}_{3}$ & $(2,3.5,5)$ & $(0.7,0.8,0.9)$ & $(0.1,0.2,0.3)$ & $(0.2,0.7,1.5)$ & 1.028 \\
\hline 3-2- $\mathrm{AC}_{3}$ & $(2,3.5,5)$ & $(0.85,0.95,1)$ & $(0,0.05,0.15)$ & $(0,0.175,0.75)$ & 0.516 \\
\hline 4-2- $\mathrm{AC}_{3}$ & $(2,3.5,5)$ & $(0.7,0.8,0.9)$ & $(0.1,0.2,0.3)$ & $(0.2,0.7,1.5)$ & 1.028 \\
\hline 5-2- $\mathrm{AC}_{3}$ & $(2,3.5,5)$ & $(0.7,0.8,0.9)$ & $(0.1,0.2,0.3)$ & $(0.2,0.7,1.5)$ & 1.028 \\
\hline 6-2- $\mathrm{AC}_{3}$ & $(5,6.5,8)$ & $(0.7,0.8,0.9)$ & $(0.1,0.2,0.3)$ & $(0.5,1.3,2.4)$ & 1.703 \\
\hline 1-3- $\mathrm{AC}_{3}$ & $(3,5,7)$ & $(0.7,0.8,0.9)$ & $(0.1,0.2,0.3)$ & $(0.3,1,2.1)$ & 1.413 \\
\hline 2-3- $\mathrm{AC}_{3}$ & $(3,5,7)$ & $(0.7,0.8,0.9)$ & $(0.1,0.2,0.3)$ & $(0.3,1,2.1)$ & 1.413 \\
\hline 3-3- $\mathrm{AC}_{3}$ & $(5,6.5,8)$ & $(0.7,0.8,0.9)$ & $(0.1,0.2,0.3)$ & $(0.5,1.3,2.4)$ & 1.703 \\
\hline 4-3- $\mathrm{AC}_{3}$ & $(2,3.5,5)$ & $(0.5,0.65,0.8)$ & $(0.2,0.35,0.5)$ & $(0.4,1.26,2.5)$ & 1.627 \\
\hline 5-3- $\mathrm{AC}_{3}$ & $(2,3.5,5)$ & $(0.7,0.8,0.9)$ & $(0.1,0.2,0.3)$ & $(0.2,0.7,1.5)$ & 1.028 \\
\hline 1-4- $\mathrm{AC}_{3}$ & $(3,5,7)$ & $(0.7,0.8,0.9)$ & $(0.1,0.2,0.3)$ & $(0.3,1,2.1)$ & 1.413 \\
\hline 2-4- $\mathrm{AC}_{3}$ & $(3,5,7)$ & $(0.7,0.8,0.9)$ & $(0.1,0.2,0.3)$ & $(0.3,1,2.1)$ & 1.413 \\
\hline 3-4- $\mathrm{AC}_{3}$ & $(3,5,7)$ & $(0.7,0.8,0.9)$ & $(0.1,0.2,0.3)$ & $(0.3,1,2.1)$ & 1.413 \\
\hline 4-4- $\mathrm{AC}_{3}$ & $(3,5,7)$ & $(0.7,0.8,0.9)$ & $(0.1,0.2,0.3)$ & $(0.3,1,2.1)$ & 1.413 \\
\hline 5-4- $\mathrm{AC}_{3}$ & $(3,5,7)$ & $(0.7,0.8,0.9)$ & $(0.1,0.2,0.3)$ & $(0.3,1,2.1)$ & 1.413 \\
\hline 6-4- $\mathrm{AC}_{3}$ & $(3,5,7)$ & $(0.5,0.65,0.8)$ & $(0.2,0.35,0.5)$ & $(0.6,1.75,3.5)$ & 2.274 \\
\hline 7-4- $\mathrm{AC}_{3}$ & $(2,3.5,5)$ & $(0.5,0.65,0.8)$ & $(0.2,0.35,0.5)$ & $(0.4,1.26,2.5)$ & 1.627 \\
\hline 8-4- $\mathrm{AC}_{3}$ & $(3,5,7)$ & $(0.7,0.8,0.9)$ & $(0.1,0.2,0.3)$ & $(0.3,1,2.1)$ & 1.413 \\
\hline 9-4- $\mathrm{AC}_{3}$ & $(3,5,7)$ & $(0.7,0.8,0.9)$ & $(0.1,0.2,0.3)$ & $(0.3,1,2.1)$ & 1.413 \\
\hline 10-4- $\mathrm{AC}_{3}$ & $(2,3.5,5)$ & $(0.5,0.65,0.8)$ & $(0.2,0.35,0.5)$ & $(0.4,1.26,2.5)$ & 1.627 \\
\hline 11-4- $\mathrm{AC}_{3}$ & $(3,5,7)$ & $(0.7,0.8,0.9)$ & $(0.1,0.2,0.3)$ & $(0.3,1,2.1)$ & 1.413 \\
\hline 12-4- $\mathrm{AC}_{3}$ & $(3,5,7)$ & $(0.7,0.8,0.9)$ & $(0.1,0.2,0.3)$ & $(0.3,1,2.1)$ & 1.413 \\
\hline 1-1- $\mathrm{AC}_{4}$ & $(2,3.5,5)$ & $(0.5,0.65,0.8)$ & $(0.2,0.35,0.5)$ & $(0.4,1.26,2.5)$ & 1.627 \\
\hline 2-1- $\mathrm{AC}_{4}$ & $(2,3.5,5)$ & $(0.7,0.8,0.9)$ & $(0.1,0.2,0.3)$ & $(0.2,0.7,1.5)$ & 1.028 \\
\hline 3-1- $\mathrm{AC}_{4}$ & $(2,3.5,5)$ & $(0.7,0.8,0.9)$ & $(0.1,0.2,0.3)$ & $(0.2,0.7,1.5)$ & 1.028 \\
\hline
\end{tabular}




\begin{tabular}{|c|c|c|c|c|c|}
\hline $\begin{array}{l}\text { Agility } \\
\text { Capability }\end{array}$ & \begin{tabular}{ll}
\multicolumn{2}{l}{ Aggregated } \\
Fuzzy Perf. \\
Rating
\end{tabular} & $\mathrm{W}_{\mathrm{ijk}}$ & $\mathrm{W}_{\mathrm{ijk}}-(1,1,1)$ & $\mathrm{FpII}_{\mathrm{ijk}}$ & $\begin{array}{l}\text { Ranking } \\
\text { Score }\end{array}$ \\
\hline 1-2- $\mathrm{AC}_{4}$ & $(2,3.5,5)$ & $(0.7,0.8,0.9)$ & $(0.1,0.2,0.3)$ & $(0.2,0.7,1.5)$ & 1.028 \\
\hline 2-2- $\mathrm{AC}_{4}$ & $(3,5,7)$ & $(0.7,0.8,0.9)$ & $(0.1,0.2,0.3)$ & $(0.3,1,2.1)$ & 1.413 \\
\hline 3-2- $\mathrm{AC}_{4}$ & $(5,6.5,8)$ & $(0.7,0.8,0.9)$ & $(0.1,0.2,0.3)$ & $(0.3,1,2.1)$ & 1.703 \\
\hline 1-3- $\mathrm{AC}_{4}$ & $(3,5,7)$ & $(0.7,0.8,0.9)$ & $(0.1,0.2,0.3)$ & $(0.3,1,2.1)$ & 1.413 \\
\hline 2-3- $\mathrm{AC}_{4}$ & $(3,5,7)$ & $(0.7,0.8,0.9)$ & $(0.1,0.2,0.3)$ & $(0.3,1,2.1)$ & 1.413 \\
\hline 3-3- $\mathrm{AC}_{4}$ & $(3,5,7)$ & $(0.7,0.8,0.9)$ & $(0.1,0.2,0.3)$ & $(0.3,1,2.1)$ & 1.413 \\
\hline 4-3- $\mathrm{AC}_{4}$ & $(3,5,7)$ & $(0.7,0.8,0.9)$ & $(0.1,0.2,0.3)$ & $(0.3,1,2.1)$ & 1.413 \\
\hline 5-3- $\mathrm{AC}_{4}$ & $(3,5,7)$ & $(0.7,0.8,0.9)$ & $(0.1,0.2,0.3)$ & $(0.3,1,2.1)$ & 1.413 \\
\hline 6-3- $\mathrm{AC}_{4}$ & $(5,6.5,8)$ & $(0.7,0.8,0.9)$ & $(0.1,0.2,0.3)$ & $(0.5,1.3,2.4)$ & 1.703 \\
\hline 7-3- $\mathrm{AC}_{4}$ & $(3,5,7)$ & $(0.7,0.8,0.9)$ & $(0.1,0.2,0.3)$ & $(0.3,1,2.1)$ & 1.413 \\
\hline 8-3- $\mathrm{AC}_{4}$ & $(5,6.5,8)$ & $(0.7,0.8,0.9)$ & $(0.1,0.2,0.3)$ & $(0.5,1.3,2.4)$ & 1.703 \\
\hline 9-3- $\mathrm{AC}_{4}$ & $(3,5,7)$ & $(0.7,0.8,0.9)$ & $(0.1,0.2,0.3)$ & $(0.3,1,2.1)$ & 1.413 \\
\hline
\end{tabular}

Now, FPIIs must be ranked. Here, Chen and Howangs left and right fuzzy ranking method is used since it not only preserves the ranking order but also consider the absolute location of each fuzzy number (Lin et al., 2005) .In Chen and Hawng's left and right fuzzy ranking method:

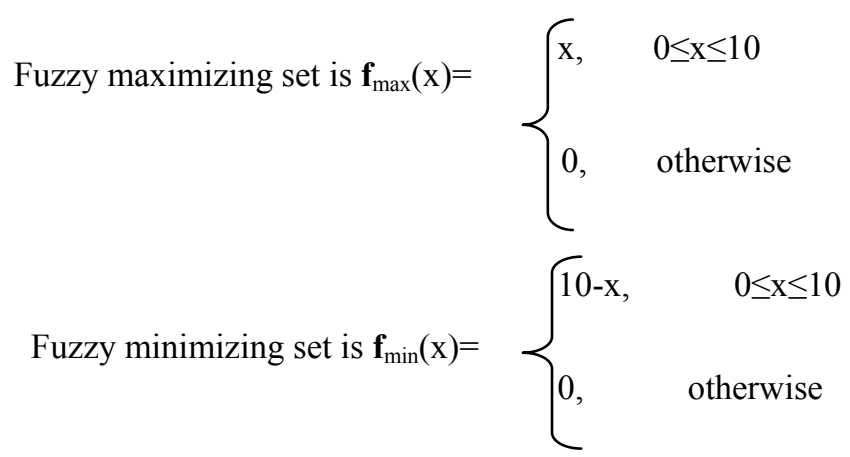

The right score of $\mathrm{F}_{\text {PII }}$ is $\mathrm{U}_{\mathbf{R}}(\mathrm{FPII})=\sup \left[\mathbf{f}_{\mathrm{FPII}}(\mathrm{x}) \wedge \mathbf{f}_{\max }(\mathrm{x})\right]$,

The left score of $\mathrm{F}_{\mathbf{p I I}}$ is $\mathrm{U}_{\mathbf{L}}(\mathrm{FPII})=\sup \left[\mathbf{f}_{\mathrm{FPII}}(\mathrm{x}) \wedge \mathbf{f}_{\text {min }}(\mathrm{x})\right]$,

Finally the total score of $\mathrm{F}_{\mathrm{pII}}$ is $\mathrm{U}_{\mathbf{T}}(\mathrm{FPII})=\left[\mathrm{U}_{\mathbf{R}}(\right.$ FPII $)+10-\mathrm{U}_{\mathbf{L}}($ FPII $\left.)\right] / 2$,

As mentioned in the pareto's principle, resources should be used in the improvement of critical obstacles to identify the most critical obstacles. Scale (1.028) was set as the management thereshold to distinguish which critical obstacles need to be improved. The results are highlightened in Table6.

The most critical factors therefore, are:

Suitable agility providers must be selected to improve these factors.

1) $\mathrm{AC}_{2-7-1}$ working on supplier on long-range plan

2) $\mathrm{AC}_{3-2-3}$ Capability in producing different product from competitors

\section{Discussion}

This paper answered the question that how agile an SCM company is. Also it showed a complete set of items which must be mentioned in evaluating agility in a SCM company.

The result of S.G.S Co. shows that it is in the middle range of agility. As it is stated in fuzzy value it assures you that the decision made in selection will not be biased. It also identifies weak factors within the organization which by improving them, the company can improve its agility index.

This paper presents a model for agility and a method to evasulate agility in SCM companies.It is fair to point out 
that this work should be seen as the starting point that investigatesagility in SCM companies. Therefore, its limitations should be taken into consideration to improve the SCM agility by other researchers. Thus, the model should be completed for SCM companies by other researchers. Also it can be computerized to decrease the time and possible errors. It would be necessary to improve the method to compare the result with another evaluation process as well.

\section{References}

Bowman, J. R. (2000). Supply chains lean to change, then-they change again. Global Logistics and Supply Chain Strategy, 10, 4-6.

Christopher, M. (2000). The agile supply chain competing in volatilemarkets. Industrial marketing management, 29, 37-44.

Dossenbach, T. (1999). Basic supply chain management = Great profits. Wood and wood product, 104(10), 105-107.

Dove, R. (2001), Response ability: The language, structure and culture of the agile enterprise. Wiley, Newyork, NY.

Duclus, L, K., Vokura, R. J., \& Lummus, R. R. (2003). A conceptual model of supply chain flexibility. International journal of physical distribution \& logestics management, 103(6), 444-456.

Eversman, M. (1999). Key to managing supply chain is extended chain. America metal market.

Failsal, M. N., Banwet, D. K., \& Shankar, R. (2007). An approach to measure supply chain agility. Int. J. industrial and system engineering, 2(1), 79-98.

Fliedner, G., \& Vokurka, R. J. (1997). Agility. Competitive inventory management Journal, 38(3), 19-24.

Giachetti, R. E., Matinez, L. D., Saenz, O. A., \& Chen, C. S. (2003). Analysis of the structural measures of flexibility and agility using a measurement theoretical framework. International journal of production economics, 86(1), 47-62.

Goldman, S. L., Negal, R. N., \& Preiss, K. (1995). Agile competitors and virtual organization: Strategies for enriching customer. New York, Van Nostrand Reinhold.

Gunasekaran, A., \& Yusuf, Y. (2002). Agile manufacturing: A taxonomy of strategic and technological imperatives. International Journal of Production Research, 40(6), 1357-1385.

Gunasekaran, A, L. K. H., \& Edvin, C. T. C. (2008). Responsive supply chain: A competative strategy in a networked economy. Omega, 36, 549-564.

Hacland, C. M. (1997). Supply chain operational performance roles. Integrated management systems, 8(2), 6-14.

Ismail, H. S., \& Sharifi, H. H. (2006). A balanced approach to building agile supply chains. Journal of Physical distribution \& logestics management, 36(6), 431-444.

Kasardaj. D., \& Rondinelli, D. A. (1998). Innovative infrastructure for agile manufacturers. Sloan management review, 39(2), 73-82.

Lengyel, A. (1994). A new thinking in manufacturing for the 21 st century. Proceeding of the 1994 Aerospace and Defense Symposium (June, pp. 1-8).

Lin, C. T., Chiu, H., \& Chu, P. Y. (2006). Agility index in the supply chain. International journal of production economics, 100, 285, 299.

Lin, C. T., Chiu, H., \& Tseng, Y. H. (2005). Agility evaluation using fuzzy logic. International journal of Production economics, 101, 353-368.

Manson, J. R., Naylor, B., \& Towill, D. R. (2000). Engineering the leagile supply chain. International Journal of agile management systems, 2(1), 54-61.

Naim, M. M. (1997). The book that changed the world. Manufacturing engineer, 13-16.

Negal, R. N., \& Bhargava, P. (1994). Agility: The ultimate requirements for world-class manufacturing performance. National Productivity review, 13(3), 331-340.

Negal, R. N., \& Dove, R. (1992). 21st century manufacturing enterprise strategy. Dethlehem, PA: Iococca Institute, Lehigh University.

O'Marah, K. (2001). A reality check on the collaboration dreams. Supply chain management review, 5(3), 23-26. 
Prince, J., \& Kay, J. M. (2003). Combining lean and agile characteristics: creation of virtual groups by enhanced production flow analysis. International Journal of production economics, 85, 305-318.

Rich, N., \& Hines, P. (1997). Supply chain management and time-based competition: The role of the supplier association. International Journal physical distribution and logistics management, 27(3/4), 210-225.

Richards, C. W. (1992). Agile manufacturing: A necessary condition for completeing in global markets. Industrial engineering, 24(12), 18-20.

Sharifi, H., \& Zhang, Z. (1999). A methodology for achieving agility in manufacturing organization: An introduction. International Journal of Production Economics, 62, 7-22.

Sharifi, H., \& Zhang, Z. (2001). Agile manufacturing in practice: Application of a methodology. International Journal of operation and production management, 21(5/6), 772-794.

Sharp, J. M., \& Irani, Z. (1999). Working towards agile manufacturing in the UK industry. International journal of production economics, 62, 155-169.

Spekmanr, E., Spear, J., \& Kummauff, J. (2002). Supply chain competency: Learning as a key component. Supply chain management: An international Journal, 7(1), 170-188.

Stevense, J. (1989). Integrity the supply chain. International Journal Physical Distribution and materials management, 19(8), 3-8.

Stuart, I. (1997). Supply-chain strategy: Organizational influence through supplier alliances. British Journal of management, $8,223-35$.

Swafford, P., Ghosh, S., \& Murthy, N. (2006). The antecedents of supply chain agility of a firm: Scale development and model testing. Journal of Operations Management, 24(2), 170-188.

Van, R. I., Harrison, A., \& Christopher, M. (2001). Measuring agile capabilities in the supply chain. International journal of operation and production management, $21(1 / 2), 126-147$.

Vázquez, B. D., Avella, L., \& Fernández, E. (2007). Agility drivers, enablers and outcomes: Empirical test of an integrated agile manufacturing model. International Journal of Operations \& Production Management, 27(12), 1303-1332.

Wong, A. (1999). Partnering through co-operative goals in supply chain relationships. Total quality management, $10(4 / 5)$.

\section{Appendix A}

\section{Fuzzy numbers arithmetic operations}

Let $\mathrm{A} 1$ and $\mathrm{A} 2$ be two triangular fuzzy numbers where $\mathrm{A} 1=(\mathrm{a} 1, \mathrm{~b} 1, \mathrm{c} 1)$ and $\mathrm{A} 2=(\mathrm{a} 2, \mathrm{~b} 2, \mathrm{c} 2)$.According to the extension principle ,the triangular fuzzy numbers addition, subtraction and multiplication operations of A1 and A2 Are defined as follows:

Fuzzy numbers addition $\oplus$ :

$$
\begin{aligned}
\mathrm{A} 1 \oplus \mathrm{A} 2= & (\mathrm{a} 1, \mathrm{~b} 1, \mathrm{c} 1) \oplus(\mathrm{a} 2, \mathrm{~b} 2, \mathrm{c} 2)=(\mathrm{a} 1+\mathrm{a} 2, \mathrm{~b} 1+\mathrm{b} 2, \mathrm{c} 1+\mathrm{c} 2) \\
& \text { Fuzzy numbers subtraction } \Theta: \\
\mathrm{A} 1 \oplus \mathrm{A} 2= & (\mathrm{a} 1, \mathrm{~b} 1, \mathrm{c} 1) \oplus(\mathrm{a} 2, \mathrm{~b} 2, \mathrm{c} 2)=(\mathrm{a} 1-\mathrm{a} 2, \mathrm{~b} 1-\mathrm{b} 2, \mathrm{c} 1-\mathrm{c} 2) \\
& \text { Fuzzy numbers multiplication } \otimes: \\
\mathrm{A} 1 \otimes \mathrm{A} 2= & (\mathrm{a} 1, \mathrm{~b} 1, \mathrm{c} 1) \otimes(\mathrm{a} 2, \mathrm{~b} 2, \mathrm{c} 2)=(\mathrm{a} 1 \times \mathrm{a} 2, \mathrm{~b} 1 \times \mathrm{b} 2, \mathrm{c} 1 \times \mathrm{c} 2)
\end{aligned}
$$

\section{Copyrights}

Copyright for this articleis retained by the author(s), with first publication rights granted to the journal.

This is an open-access article distributed under the terms and conditions of the Creative Commons Attribution license (http://creativecommons.org/licenses/by/3.0/). 